\title{
学生の和食（日本の家庭料理）の喫食状況
}

堀 光代* ·平島 円**・磯部由香**

( *岐阜市立女子短期大学食物栄養学科, ${ }^{* *}$ 三重大学教育学部)

(令和 2 年 4 月 21 日受付, 令和 2 年10月 9 日受理)

\section{The study of the eating circumstances of washoku (Japanese traditional homemade meals) among college students}

\author{
Mitsuyo Hori*, Madoka Hirashima**, Yuka Isobe ${ }^{* *}$ \\ *Department of Food and Nutrition, Gifu City Women's College,
}

7-1, Hitoichiba Kitamachi, Gifu-shi, Gifu, 501-0192

**Faculty of Education, Mie University, 1577, Kurimamachiya-cho, Tsu-shi, Mie, 514-8507

$$
\begin{aligned}
* \text { \% 501-0192 } & \text { 岐阜県岐阜市一日市場北町 7-1 } \\
* * \text { 厂 514-8507 } & \text { 三重県津市栗真町屋町1577 }
\end{aligned}
$$

\begin{abstract}
A survey was conducted in 2016 among 509 college students to investigate the knowledge and eating experience of 23 kinds of traditional homemade Japanese meals (washoku) and their preparing ways. The respondents were divided into two groups by living arrangements. It was found that more than $90 \%$ of students had knowledge and experience of eating washoku, and it was mostly made at home. However, some washoku were eaten with less frequency, and some homemade washoku were not eaten at home. Analyzing the differences in eating washoku by living arrangements, students living away from home ate washoku with less frequency of eating and tended not to make washoku at home compared with students commuting from home. These results implied that traditional homemade Japanese meals, washoku, would no longer be made and eaten at home in the future.
\end{abstract}

\section{1.はじめに}

日本の伝統的な食文化である和食は，ユネスコ世界無 形文化遺産として平成25年（2013年）に登録された。和 食または和食文化は,「多様で新鮮な食材とその持ち味 の尊重」「健康的な食生活を支える栄養バランス」「自然 の美しさや季節の移ろいの表現」「正月などの年中行事 との密接な関わり」の 4 つの特徴をもち ${ }^{1-4)}$, 自然を尊 重しながら, 外国の食文化を取り入れて発達したもので ある。

和食のユネスコ世界無形文化遺産への登録は, 日本人 が和食を再認識するきっかけとなり, 登録されてから, 学校給食においても米飯の提供が増えている ${ }^{3)}$ 。しかし， 和食献立の日の給食の残食率は高いとも報告 ${ }^{5}$ さされてい る。また, 日本人の米の消費量は減少し続けている ${ }^{6)}$
とから, 米飯を主とした和食の形態が変化している, あ るいは和食の喫食頻度は減少していると推察される。こ れは，日本の伝統的な文化や習慣について関心が低い人 も多く，日本の食文化を子どもたちに伝承している人は 40\%程度で，55\%程度の人が伝承していない現状 ${ }^{7)}$ が関 係していると考えられる。

それに加え, 中食産業の売り上げは近年成長し続けて いる ${ }^{8)}$ 。中食産業の成長により, 和食に限らず多様な料 理が販売されており，手軽に利用できることから，料理 の選択肢は広がっている。また，料理だけでなく、ペッ トボトルをはじめとする緑茶飲料の売り上げも増加して おり ${ }^{9)}$, 家庭で茶葉から緑茶を淹れることも少なくなっ ている10)

そこで本研究では，これからの和食文化を担う若い世 代である学生の日本の家庭料理である和食に対する認知 
度，喫食経験，喫食頻度と食べ方（供食方法）について 調查し，和食の契食状況について分析した。これにより， 今後の和食の受容について検討した。

\section{2. 調査方法}

調査対象者は大学拈よび短期大学の $1 \sim 4$ 年生509人 とした。アンケート対象者の概要を表 1 に示す。対象者 の内訳は，大学生のほうが短期大学生よりもわずかに多 かったが，学年は 1 年生が半数以上を占め，ほとんどが 10歳台だった。また，女性が約80\%と多く，自宅から通 学する学生が約70\%だった。学生の調理頻度は, 週 3 回 以上あるいは週 1〜2 回調理する, ほとんど調理しない が同程度に分散していた。

このような学生を対象とし, 日本の家庭料理の認知度, 喫食経験，供食方法についてのアンケート調査を2016年 に行った。アンケート用紙には料理名とともに料理を写

表 1 アンケート対象学生509人の概要*

\begin{tabular}{|c|c|c|}
\hline \multirow{4}{*}{ 年齢 } & 18歳 & 117 人 $(23.1 \%)$ \\
\hline & 19歳 & 210 人 (41.5\%) \\
\hline & 20歳 & 82 人 $(16.2 \%)$ \\
\hline & $21 \sim 24$ 歳 & 97 人 $(19.2 \%)$ \\
\hline \multirow{2}{*}{ 高等教育機関 } & 大学 & 293 人 $(57.6 \%)$ \\
\hline & 短期大学 & 216人 $(42.4 \%)$ \\
\hline \multirow{4}{*}{ 学年 } & 1 年生 & 298 人 $(58.7 \%)$ \\
\hline & 2 年生 & 109 人 (21.5\%) \\
\hline & 3 年生 & 26人 $(5.1 \%)$ \\
\hline & 4 年生 & 75 人 $(14.7 \%)$ \\
\hline \multirow{2}{*}{ 性別 } & 男性 & 98 人 $(19.3 \%)$ \\
\hline & 女性 & 410 人 $(80.7 \%)$ \\
\hline \multirow{2}{*}{ 居住形態 } & 自宅生 & 348 人 $(68.6 \%)$ \\
\hline & 下宿生 & 159人 $(31.4 \%)$ \\
\hline \multirow{3}{*}{ 調理頻度 } & 週 3 回以上 & 149 人 $(29.3 \%)$ \\
\hline & 週 1 日〜 2 日 & 166 人 $(32.7 \%)$ \\
\hline & ほとんどしない & 193 人 $(38.0 \%)$ \\
\hline
\end{tabular}

※無回答，不明者は除く
真で示し，料理名を知らなくても回答できるようにした。 アンケート調査はヘルシンキ宣言の精神に則り，倫理指 針を順守し, 調查結果が研究目的にのみに使用され, 個 人が特定されないことを併記した自記式質問用紙を配布 して行った。

和食についての定義は議論のあるところだが，本研究 では，家庭料理のうち，蒸す，ゆでる，煮る調理を主と して，だしを用いること，あるいは槒油味または味噌味 で，箬で食べるもの ${ }^{11}$ を和食とした。また，著者らのこ れまでの研究 ${ }^{12)}$ と比較できるように, 家庭料理のなかか ら 22 種類の和食と, これに緑茶を加えた 23 種類を和食と して選んだ（表 2 および表 3 参照）。

得られたデータからユークリッド距離を計算し， ウォード法によるクラスター分析を用いて，和食の分類 を行った。また，対象者を居住形態により分類して分析 し, 比較した。得られた回答は集計し， $\chi^{2}$ 検定により 有意差検定を行った。有意水準は $5 \%$ 未満とした。 $\chi^{2}$ 值とともに期待度数を求め, 実測値数と残差分析を行う ことにより差について検討した。

\section{3. 結果と考察}

\section{（1）和食の認知度と喫食経験, 喫食頻度}

調査対象者の全学生509人が日本の家庭料理のなかの 和食22種類と緑茶を合わせた 23 種類（以下，和食）につ いて「知っている」と回答した割合を集計し，回答割合 ごとの和食名を表 2 に示す。いずれの和食に扔いても 「知っている」と回答された割合は $95 \%$ 以上だった。そ のうち，炊き込みご飯や親子どんぶりなど10種類の和食 は100\%，すなわち，全員の学生が知っており，23種類 の和食の認知度は高いことがわかった。

表 3 には，学生が「食べたことがある」と回答した割 合ごとの和食名を示す。いなり寿司，みそ汁や焼き魚な ど 5 種類の和食では, 全学生（100\%）に喫食経験があっ た。「食べたことがある」と回答された割合がもっとも 低かったのは白和えの $90.5 \%$ たった。ほとんどの学生に おいて，23種類の和食を食べた経験のあることがわかっ た。

次に，哭食経験のある学生に対して食べる頻度を「ほ

\begin{tabular}{|c|c|}
\hline $\begin{array}{c}\text { 回答割合 } \\
(\%)\end{array}$ & 和 食 \\
\hline 100 & $\begin{array}{l}\text { 炊き込みご飯，親子どんぶり，ちらし寿司，巻き寿司，いなり寿司， } \\
\text { みそ汁，焼き魚，天ぷら，きんぴらごぼう，緑茶 }\end{array}$ \\
\hline $95 \sim 99$ & $\begin{array}{l}\text { かきたま汁, すまし汁, 豚汁 (さつま汁), 肉じゃが, } \\
\text { 炒り鶏 (筑前煮), さばの味噌煮, ぶりのてりやき, だし巻き卵, } \\
\text { 茶わん蒸し, かぼちゃの煮物, ほうれん草のごま和え, } \\
\text { きゅうりとわかめの酢の物, 白和え, }\end{array}$ \\
\hline
\end{tabular}




\begin{tabular}{|c|c|}
\hline $\begin{array}{c}\text { 回答割合 } \\
(\%)\end{array}$ & 和 食 \\
\hline 100 & いなり寿司，みそ汁，焼き魚，天ぷら，きんぴらごぼう \\
\hline $95 \sim 99$ & $\begin{array}{l}\text { 親子どんぶり, 炊き込みご飯, ちらし寿司, 巻き寿司, かきたま汁, } \\
\text { すまし汁, 豚汁 (さつま汁), 肉じゃが, さばの味噌煮, } \\
\text { ぶりのてりやき, だし巻き卵, 茶わん蒸し，かぼちゃの煮物， } \\
\text { ほうれん草のごま和え，緑茶 }\end{array}$ \\
\hline $90 \sim 94$ & 炒り鶏 (筑前煮), きゅうりとわかめの酢の物, 白和え \\
\hline
\end{tabular}

とんど毎日」「週 1 3 回」「月 $1 \sim 3$ 回」「年 $1 \sim 3$ 回」 「ほとんど食べない」から選択回答させた結果を図 1 に 示す。な押，「ほとんど毎日」食べると回答された割合 は低かったため，「ほとんど毎日」と「週 1 的回」を 合わせて「週 1 回以上」として集計した。これらの喫食 頻度によりクラスター分析を行ったところ，4つのグ ループに分類された。グループ 1 は「週 1 回以上」食心゙ ると回答された割合が高かったみそ汁と緑茶の 2 種類 だった。これらの 2 種類については,「ほとんど毎日」 食べると回答した割合も， 久そ汁が31. 2\%（509人中 163 人)，緑茶が $41.4 \%$ （506人中 210 人）と，比較的高かった。 したがって，みそ汁と緑茶は日常的に食べられる和食た と考えられる。

グループ 2 は, 「月に $1 \sim 3$ 回」食べられる割合が高 い和食 10 種類で，焼き魚，だし巻き卵，ほうれん草のご ま和えなどが分類された。これらの和食は，月に数回食 卓に上がる定番の献立の一品だと考えられる。

グループ 3 は,「年に $1 \sim 3$ 回」食べられる割合がもっ とも高いが，「月に $1 \sim 3$ 回」食べられる割合も高い和 食 9 種類だった。すまし汁, さばの味噌煮, 炒り䳕（筑 前者)，寿司類が分類され，これらの和食は定期的だが， たまにしか食べられない料理だったり，特別な日（ハレ の日）などに食べられる料理だったりするのではないか と考えられる。同じアンケート対象者に「赤飯」の䒜食 頻度を尋齐たところ，「年に $1 \sim 3$ 回」食べると回答さ れた割合が $50.9 \%$ (505人中 257 人) と高かった。したがっ て, 年に数回食べるものには, 通過儀礼や行事食, ある いは八レの日に食べる和食が含まれると推察される。

グループ4は，「ほとんど食べない」割合の高いきゅ うりとわかめの酢の物と白和えの 2 種類だった。これら の 2 種類の和食は, 喫食経験があっても, 普段の食事で は食べられなくなりつつある和食であることがわかった。

\section{（2）和食の供食方法}

和食について「食べたことがある」と回答した学生に 対して，それらを食べるときに，もっとも多い供食方法 を，「手作り」「購入」「外食」のなかから選択させ，内食， 中食, 外食で食べる割合についてもクラスター分析によ
り，分類した。その結果を図 2 に示す。供食方法では 3 つのグループに分類された。グループ1は「手作り」の ものを食べる割合の高い，すなわち，内食で食べられる， 肉じゃがやかぼちゃの煮物，みそ汁など15種類だった。 比較的多くの和食が内食で食されていることがわかった。 そのなかで, 肉じゃがについては, 購入して食べる料理 ではなく，家庭で作って食べる料理だと認識されている という報告 ${ }^{13)}$ がある。本研究の結果からも肉じゃがは家 庭で作って食べられることが多い料理だった。

グループ 2 は, 内食の割合も比較的高いが,「購入（中 食)」や「外食」を利用することも多いもので，きゅう りとわかめの酢の物やさばの味噌煮, 天ぷらなど 6 種類 が分類された。スーパーマーケットやコンビニエンスス トアで一般惣菜として販売されているものがこのグルー プに入った。天ぷらはスーパーマーケットでの購入頻度 がすべての惣菜のなかで第 4 位に入っている ${ }^{8)}$ 。そのた め, 中食で食べられる割合の高い和食だったと考えられ る。また, 緑茶は「手作り (家で茶葉から淹れる)」の ものが54.1\%だったが，「購入」したものを飲む割合が $41.6 \%$ と拮抗していた。上述した家で茶葉から緑茶を淹 れることが少なくなり，ペットボトルなどの市販の緑茶 を飲むことが多くなっている結果と一致した。

グループ 3 は,「購入」する割合が高い巻き寿司とい なり寿司の 2 種類だった。巻き寿司はスーパーマーケッ トだけでなく、コンビニエンスストア，百貨店や専門店 などすべての販売店での購入頻度の高さランキングの第 5 位である ${ }^{8)}$ 。また，これまでの調査 ${ }^{12)} に よ り ，$ 学生が 巻き寿司といなり寿司を作ることができると回答した割 合は，いずれも60\%以下と低いことがわかっている。寿 司は，喫食頻度も低いためか，学生にとっては，すでに 家庭で作る和食ではなく，中食を利用する和食だといえ る。また，今回は手作りのものを食べる割合が比較的高 かったちらし寿司においても，学生が作ることができる と回答した割合は $60 \%$ 以下だった ${ }^{12}$ 。そのため, 寿司全 般に挍いては，家で食べたとしても家庭では作られず, 今後ますます中食を利用する和食になるのではないかと 推察される。 


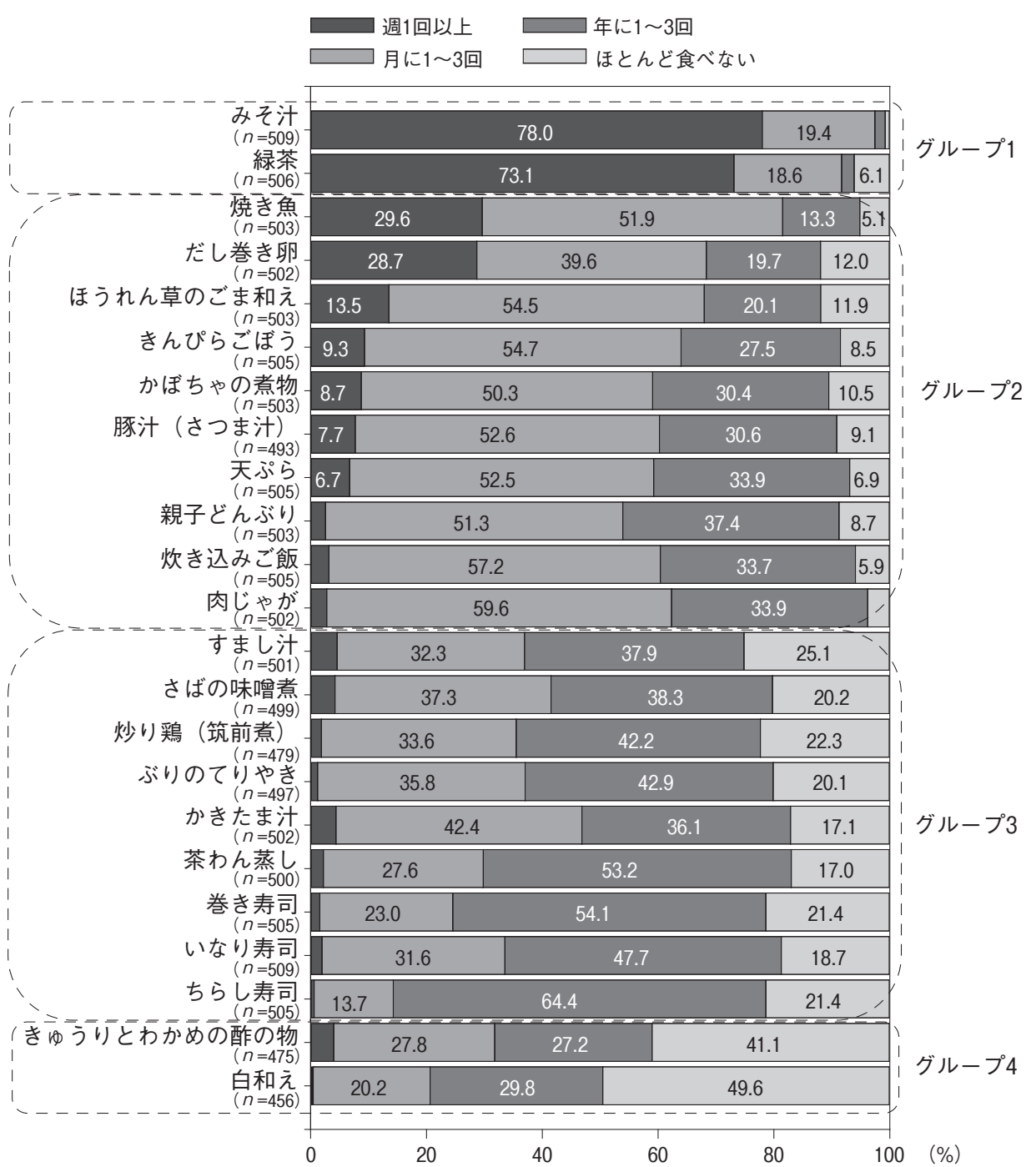

図 1 学生の22種類の日本の家庭料理と緑茶（和食）の喫食頻度* ※喫食経験のある学生を対象として頻度の割合を算出した。

\section{（３）和食の喫食頻度と供食方法に及ぼす居住形態の影響} 次に, これからの和食の継承について調べるために, 学生を自宅生と下宿生に分類し, 和食の喫食頻度につい て検討した。図1のグループ1とグループ 2 に分類され た比較的喫食頻度の高い12種類の和食について分析した 結果を図 3 に示す。緑茶と豚汁を除く 10 種類の和食の契 食頻度は, 自宅生のほうが下宿生よりも高かった。これ ら10種類の和食の喫食頻度の差は,「週 1 回以上」と「ほ とんど食べない」の 2 つの喫食頻度の両方またはいずれ にかあった。

自宅生のほうが「週 1 回以上」食べる割合が高く,「ほ とんど食べない」割合が低かった和食は，みそ汁，焼き 魚、きんぴらごぽう，かぼちゃの煮物の 4 種類だった。 また，「週 1 回以上」食べる割合に差はなかったが，自 宅生のほうが「ほとんど食べない」割合の低かったもの は，天ぷら，親子どんぶり，炊き込みご飯，肉じゃがの 4 種類だった。これら 8 種類の和食は，下宿生のほうが 自宅生よりも契食頻度が低く，自分で食べる料理を選択
する下宿生では，食べることは少ないと考えられる。そ のため, 自宅生に执いても，現在は自宅で家族と一緒に 食べることから，喫食頻度は高かったが，今後，自分で 食べる料理を選択するようになると，選ばれなくなる可 能性があると推察される。

さらに，自宅生のほうが下宿生よりも「週 1 回以上」 食べる割合が高かったが，「ほとんど食べない」割合に 差のなかったものは，だし巻き卵，ほうれん草のごま和 えの 2 種類だった。これらの和食は,「ほとんど食べない」 割合が約10\%と，居住形態による差がなかったことから， 自ら選択して食べる和食だと考えられる。しかし，下宿 生のほうが喫食頻度の低いことより，自分で料理を選択 する場合には，食べる機会が少なくなる和食だと考えら れる。

次に，供食方法の居住形態による違いについて分析し た。図 2 に示したグループ1に分類された手作りでの契 食割合の高かった15種類の和食について, 自宅生と下宿 生が食べるときに，もっとも多い供食方法について選択 


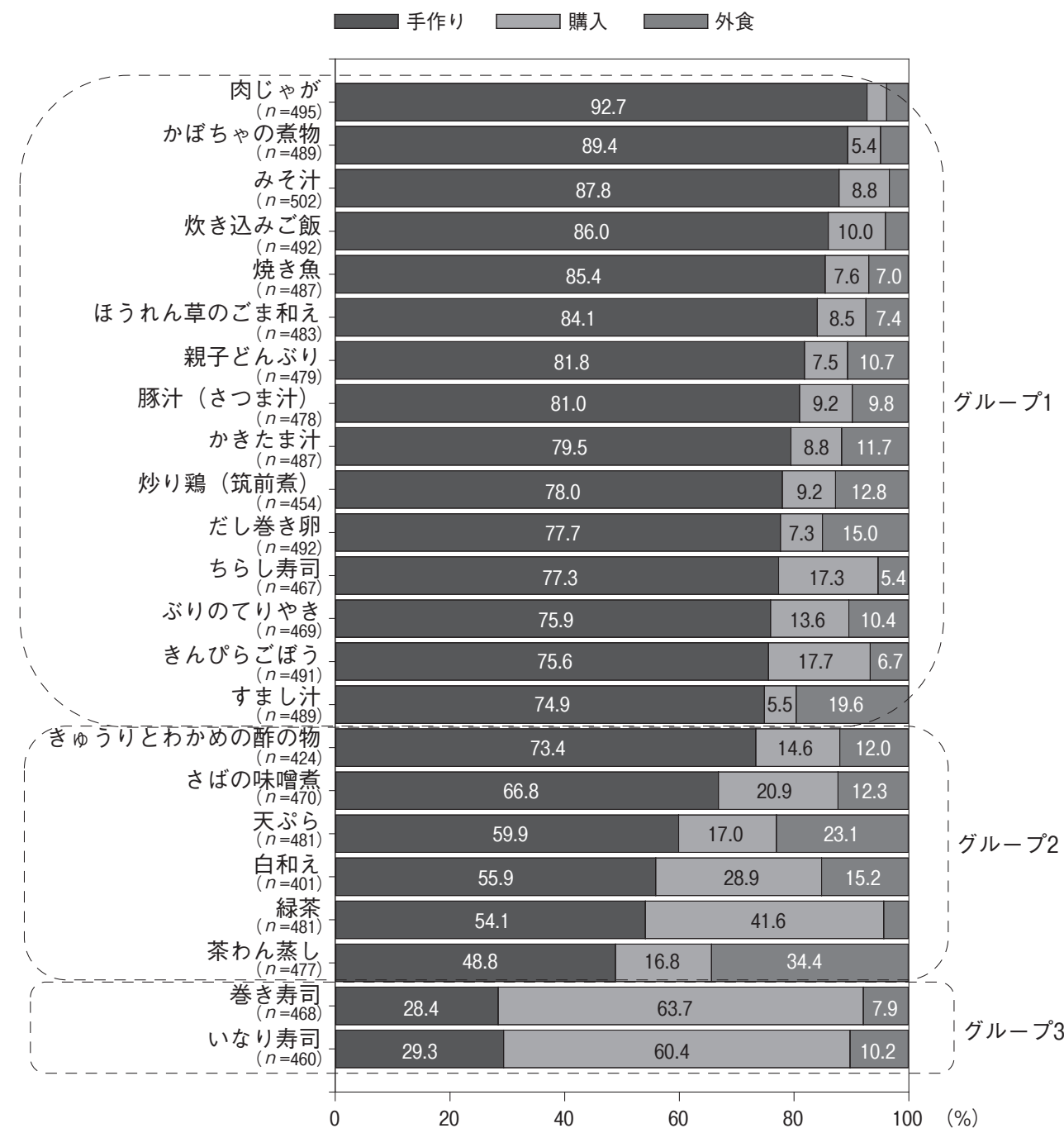

図 2 学生が22種類の日本の家庭料理と緑茶（和食）を食べるときの供食方法

回答した結果を図 4 に示す。いずれの和食においても, 自宅生のほうが下宿生よりも手作りのものを食べる割合 が高かった。それに対し，下宿生は炒り鶏（筑前煮）以 外の14種類の和食を外食する割合が自宅生よりも高かっ た。また, 肉じゃが, みそ汁, 焼き魚, 豚汁の 4 種類に ついては, 購入する割合も下宿生のほうが自宅生より高 かった。

自宅生と下宿生が，週 3 回以上調理する割合は，それ ぞれ $14.7 \%$ (348人中 51 人) と $61.6 \%$ (159人中 98 人) だっ た。これまでの報告 ${ }^{12,14,15)}$ と同様に, 調理頻度は下宿生 のほうが高かった $(p<0.001)$ 。しかし，下宿生が和食 を手作りで食べる割合は低いことから，本研究で調査し た和食以外の料理を作ると考えられる。

そこで，学生が作る料理について，これまでの調査結 果 ${ }^{12,14,15)}$ により検証した。

大学や専門学校の新入生の $80 \sim 100 \%$ と多くの学生は, みそ汁を調理できることがわかっている ${ }^{12)}$ 。また, 焼き魚, ほうれん草のごま和え, 親子どんぶり, 豚汁, だし巻き 卵は，60〜80\%の学生が調理できるとされている。す なわち, 学生は和食を作れないわけではない。
しかし，これまでの研究 ${ }^{14,15)}$ で学生が作る料理につい て自由記述にて調査したところ，学生がよく作る料理の 上位は, カレーライス, チャーハン，才ムライス，野菜 炒め, みそ汁だった。今回調査した和食のなかでは, み そ汁のみがよく作る料理の上位だった。また，下宿生は， どんぶりを自宅生よりも作る割合が高く, 鍋物, うどん・ そばといった今回の調査になかった和食を作る割合が自 宅生よりも高かった ${ }^{15)}$ 。

したがって，下宿生のほうが自宅生よりも今回調査し た和食を手作りで食べる割合が低い原因は，今回調査し ていない和食や, 和食以外の料理を作る，または選択す ることが多いためだと考えられる。手作りの和食を食べ る割合の高い自宅生においても，学生自身の調理頻度は 低いため，家族が用意した和食を食べているにすぎず， 今後，自分で食事を選択するときには，和食の喫食頻度， 特に手作りのものを食べる頻度は低くなると推察される。

\section{4.おわりに}

大学生と短期大学生における日本の家庭料理のなかの 和食の認知度, 喫食経験, 喫食頻度, 供食方法について 


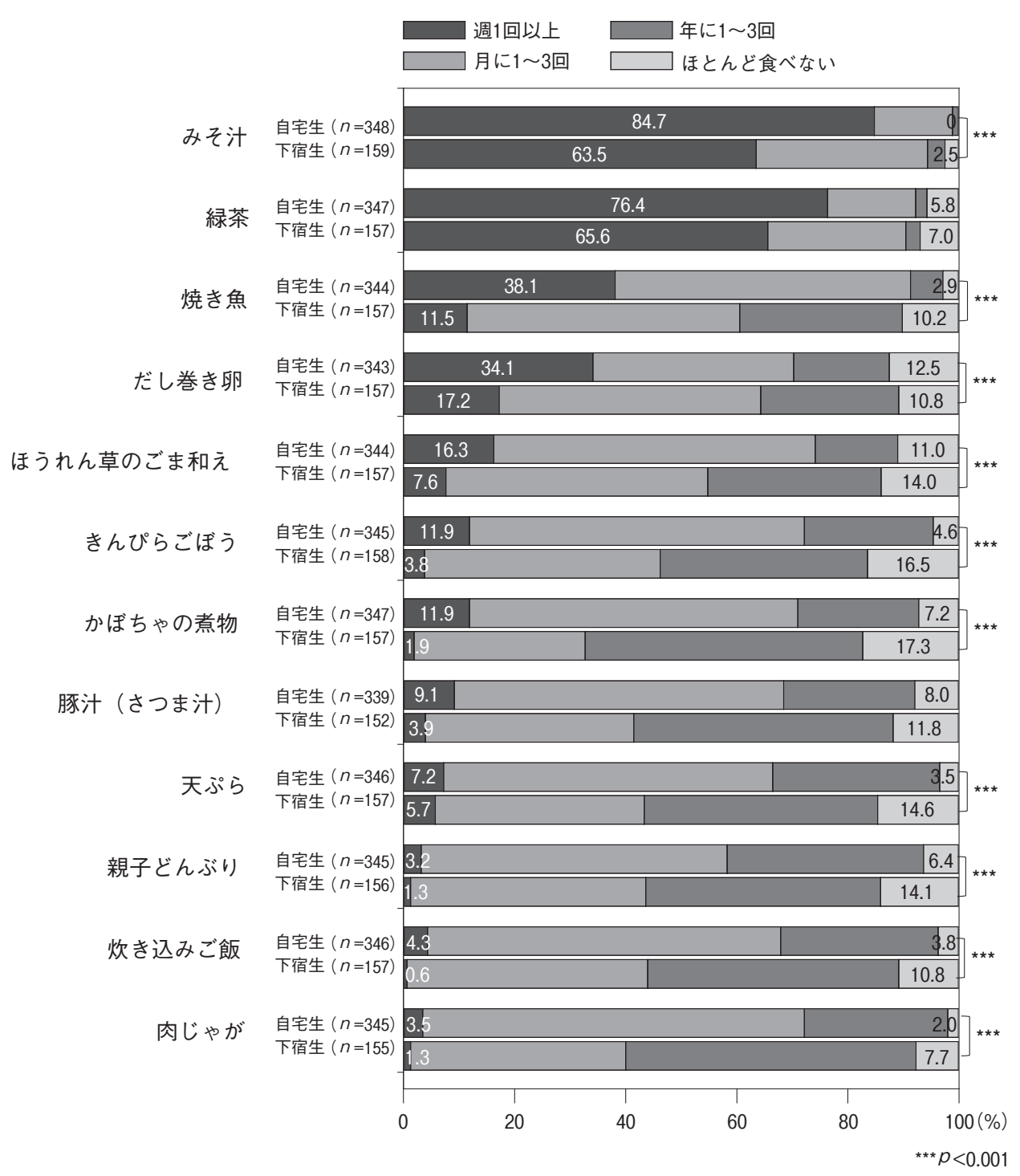

図 3 自宅生と下宿生における12種類の日本の家庭料理と緑茶（和食）の喫食頻度\%の違い ※契食経験のある学生を対象として頻度の割合を算出した。

調査した。その結果，学生の和食の認知度と喫食経験は 高いことがわかった。しかし，契食頻度の結果から推察 すると，きゅうりとわかめの酢の物と白和えは食べられ なくなりつつある和食たと考えられた。また，喫食頻度 は比較的高くても，巻き寿司といなり寿司は家庭で作ら れることの少ない和食になりつつあった。

そのほかの和食についても家族とともに暮らす自宅生 では，契食頻度は比較的高かったが，自分で食べる料理 を選択する下宿生の喫食頻度は低いことから，将来的に は和食が食べられる頻度はますます低くなると推察され る。また，和食が食べられたとしても家庭で作られるこ とは少なくなることが示唆された。今回の調査では，家 庭での調理環境について調べなかったため, 調理器具な どがないために，特に下宿生においては，家庭で作るこ とのできない和食もある可能性がある。調理環境につい ての調査は今後の課題である。

食文化だけでなく，文化を継承するためには，文化に
関心をもち，体験することが重要だと考えられる。和食 を継承するためには，学校給食をはじめ，家庭で食べら れることの少なくなっている和食を食べる機会を増やす 必要がある。食べることを経験することで，たとえ手作 りのものを食べずとも，中食や外食で和食を選ぶように なることが期待される。また，教育機関では和食の意義 や，栄養学的な利点なども学習させる機会を今以上に設 け，若い世代に興味や関心をもたせることが必要だと考 えられる。

本研究を行うにあたりアンケートにご協力いただいた 大学生および短期大学生の皆さんに感謝申し上げる。

\section{利益相反}

本研究に関する開示すべき利益相反はない。 


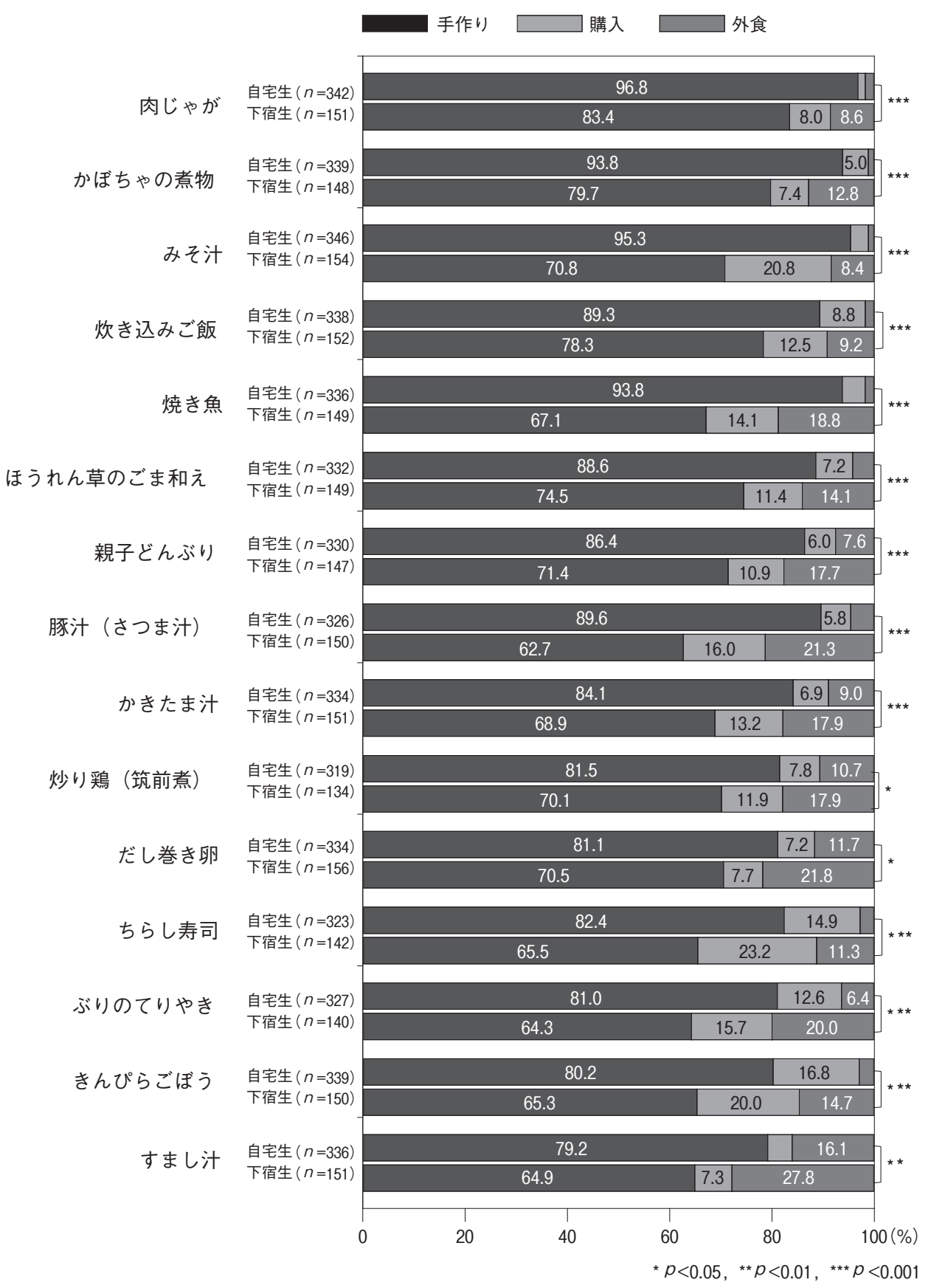

図 4 自宅生と下宿生における15種類の日本の家庭料理（和食）の供食方法の違い

\section{文献}

1）農林水産省 :「和食」が世界無形文化遺産に登録されまし た!, http://www.maff.go.jp/j/keikaku/syokubunka/ich/ (2013)（2020年 3 月25日閲覧）

2）熊倉功夫, 江原絢子：「和食文化ブックレット 1 和食と は何か」, 思文閣出版, 京都, (2015)

3 ）江原絢子：ユネスコに登録された「和食」とは何か一そ の特徵と継承一, 食生活学会誌, 28，3-5（2015）

4）大久保洋子：食文化と食育「和食：日本の伝統的な食文 化一正月を例として」(ユネスコ無形文化遺産に登録)，日 本食育学会誌，13，183-188（2019）

5 ）鹿内信善, 渡辺聡, 計良志織, 石田ゆき：看図アプロー 千協同学習で克服する和食給食食べ残し一授業モデルの提
案一, 福岡学院女子大学紀要, 17, 7-13 (2016)

6 ）農林水産省：米をめぐる関連資料, http://www.maff. go.jp /j/seisan/keikaku/soukatu/mr.html（2018）（2020年 3 月 25 日閲覧)

7 ）文化庁地域文化創生本部事務局：平成30年度生活文化調 查研究結果報告書 (2019)

8）日本惣菜協会：2019年度版 惣菜白書一ダイジェスト版 一, http://www.nsouzai-kyoukai.or.jp/outline/publishing/ syosekikounyu/（2019）（2020年 3 月25日閲覧）

9 ）食品産業新聞社 Web ニュース：2018年の緑茶飲料市場規 模，13年ぶりに過去最高の見通し / 茶系飲料動向, https:// www.ssnp.co.jp/news/beverage/2018/11/2018-1121-1754-14. $h t m l$ (2018) (2020年 3 月25日閲覧)

10）農林水産省：茶をめぐる情勢, https://www.maff. go. jp/ 
日本食生活学会誌 Vol.31 No.3（2020）

$\mathrm{j} /$ seisan/tokusan/cha/attach/pdf/ocha-17.pdf (2016) (2020 年 3 月25日閲覽)

11）江原絢子：「和食」：日本人の伝統的な食文化.「日本の食 文化一『和食』の継承と食育」(江原絢子, 石川尚子編), アイ・ケイコーポレーション, 東京 (2019)

12）平島円, 磯部由香, 堀光代, 大学抢よび専門学校生の料 理習得に及ぼす要因, 食生活研究, 36, 1-14（2015）

13）日本調理科学会近畿支部・煮る分科会：関西地区の女子
学生家庭における煮る調理に関する実態調査, 日本調理科 学会誌，37，71-75（2004）

14）平島円, 磯部由香, 堀光代 : 大学および専門学校新入生 の調理に対する意識, 日本調理科学会誌, 48, 207-215 (2015)

15）平島円, 磯部由香, 堀光代 : 大学掞よび専門学校生の調 理に対する意識と実践度の在学中の変化 第 1 報, 日本調 理科学会誌, 52, 335-344（2019） 